ZalǫcZnilf

DOI $10.21697 / z k .2021 .8 .16$

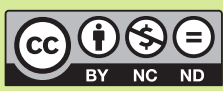

Załącznik Kulturoznawczy 8/2021

TEMAT NUMERU (2): DOSTOJEWSKI, SCHULZ, GOMBROWICZ I INNI „PROZAICY SCENICZNI”

\title{
OD POWIEŚCI FILOZOFICZNEJ DO TEATRU (POST)EPICKIEGO? KOSMOS WITOLDA GOMBROWICZA W INSCENIZACJI JERZEGO JAROCKIEGO'
}

KatARZYNa Gotos-DąBROWSKa

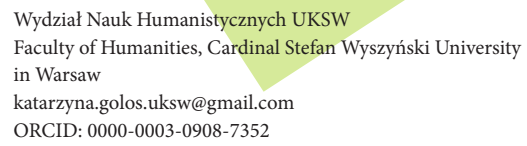

\section{GOMBROWICZ W TEATRZE}

Twórczość Witolda Gombrowicza nie miała łatwych początków na polskich scenach teatralnych, zarówno $z$ uwagi na ingerencje cenzury, jak i z powodu przeszkód stawianych potencjalnym inscenizatorom przez samego pisarza. W 1956 roku Tadeusz Byrski rozpoczął pracę nad inscenizacją Ślubu, jednak Gombrowicz nie wyraził zgody na premierę dramatu w prowincjonalnym kieleckim teatrze. Pisał wówczas do reżysera: „bomba nie jest po to, by wybuchała na peryferiach"2. Autor Ferdydurke nie zaaprobował również pomysłu realizacji Iwony, księżniczki Burgunda w teatrze Cricot 2. Pisarz żywił obawy wobec eksperymentalnego charakteru teatru Tadeusza Kantora, skupiającego się dotychczas przede wszystkim na wystawianiu dramatów Witkacego. Ostatecznie pierwszą polską inscenizacją tego dzieła była Iwona, księżniczka Burgunda z 1957 roku, w reżyserii Haliny Mikołajskiej (Teatr

$1 \mathrm{~W}$ artykule powołuję się na analizę nagrania będącego rejestracją bezpośredniej transmisji przedstawienia teatralnego wystawionego przez aktorów Teatru Narodowego w Warszawie. (Realizacja telewizyjna: Józef Kowalewski, montaż: Beata Barciś. Szczegółowe informacje: https://filmpolski.pl/fp/index.php?film=524839 [dostęp 21.05.2021].

2 List Witolda Gombrowicza do Tadeusza Byrskiego, „Słowo Ludu” 1957, nr 35, s. 3. 
Dramatyczny w Warszawie). Z kolei nieoficjalna premiera Ślubu odbyła się 6 kwietnia 1960 roku - jakby na złość autorowi - w studenckim teatrze funkcjonującym przy Politechnice Gliwickiej. Spektakl wyreżyserowany przez Jerzego Jarockiego mimo zainteresowania publiczności został szybko zdjęty z afisza na skutek ingerencji cenzury.

Nieco bardziej oficjalną krajową premierą drugiego dramatu Gombrowicza (zrealizowaną, rzecz jasna, nie bez przeszkód) była inscenizacja w warszawskim Teatrze Dramatycznym (1974)3. Jarocki wystawił Ślub w sumie ośmiokrotnie. Na scenach krajowych m.in. w krakowskim Teatrze Starym (1992), a za granicą w Schauspielhaus Zürich (1972) i w Nowym Sadzie w Srpsko narodno pozorište - Dramski Centar (1981), za każdym razem konfrontując dramat ze zmieniającą się rzeczywistością historyczną. Reżyser udowadniał sceniczność utworów autora Ferdydurke, nie tylko przygotowując kolejne realizacje Ślubu, ale również poprzez wystawianie jego prozy.

Przedstawieniem poświęconym dorobkowi pisarza, ale i samemu Witoldowi Gombrowiczowi jako bohaterowi własnej twórczości, było Błądzenie. Spektakl z 2004 roku to opowieść spleciona z fragmentów różnych dzieł, zarówno prozatorskich, jak i dramatycznych (a mianowicie z: Dziewictwa, Ferdydurke, Iwony, księżniczki Burgunda, Testamentu, Dzienników, Operetki, Historii, Przewodnika po filozofii w sześć godzin i kwadrans oraz książki autorstwa żony pisarza Gombrowicz w Europie 1963-1969). Ostatnim gombrowiczowskim spektaklem Jerzego Jarockiego był Kosmos. W powieści tej - jak mówił sam reżyser - Gombrowicz „doprowadza do absurdu natrętną ludzką tęsknotę do uporządkowania i usensownienia świata"4. Premiera spektaklu miała miejsce 16 października 2005 roku w stołecznym Teatrze Narodowym.

Jerzy Jarzębski pisząc o teatralności dzieł Gombrowicza, zwrócił uwagę na potencjał sceniczny „człowieka gombrowiczowskiego”, na wskroś teatralnego, świadomego nieautentyczności swojego istnienia, odgrywania ról i występowania przed audytorium ${ }^{5}$. Świat tej prozy, jak zaznacza badacz: „przepełnia żywioł gry, zgrywy, udawania. Sceny projektowane w opowia-

3 B. Guczalska, Jerzy Jarocki. Artysta teatru, Kraków 1999, s. 179.

4 S. Frołow, J. Jarocki, Polska szkoła interpretacji Rosji, „Nowaja Polsza” 2006, nr 7-8, s. 23.

5 J. Jarzębski, Natura i teatr. 16 tekstów o Gombrowiczu, Kraków 2007, s. 88. 
daniach i powieściach mają charakter spektaklu, rozgrywają się na oczach widzów i wobec nich”. Bohater Gombrowicza nie „jest”, ale „zachowuje się jak" ". Powszechnie wiadomo, że liczne sceny z utworów prozatorskich pisarza są naznaczone swoistą teatralnością - koniecznością występowania przed innymi i oglądania innych. Dotyczy to zarówno dramatów, jak i powieści. Jednak owa teatralność, udawanie, reżyserowanie i kreowanie rzeczywistości nie są tożsame z „podatnością na teatralizację”, tym bardziej, że często znajdują wyraz w pierwszoosobowej narracji, a nie w dialogach. Przeszkodami czy trudnościami pojawiającymi się w procesie adaptowania są więc odnarratorskie komentarze i autokomentarze tłumaczące świat przedstawiony oraz relacjonujące przebieg zdarzeń. Zawierają one informacje, które z zasady trudno przedstawić ${ }^{8}$.

Jerzy Jarocki w Kosmosie uwypukla teatralność „człowieka gombrowiczowskiego”, jednocześnie udowadniając swego rodzaju „plastyczność" narracji autora Ferdydurke, jej dialogiczny i dramatyczny potencjał. $\mathrm{W}$ niniejszym artykule przedstawię zarys metody dramatyzacji powieści Gombrowicza ${ }^{9}$ stosowanej przez Jerzego Jarockiego oraz zaprezentuję niektóre tropy interpretacyjne sugerowane przez twórcę spektaklu. Przeanalizuję również sposób, w jaki inscenizatorzy (reżyser wraz ze scenografem) poprzez kreowanie przestrzeni scenicznej odsyłają widza do owych odczytań oraz jak tworzą sensy za pomocą rozwiązań scenograficznych.

\section{USCENICZNIENIE KOSMOSU}

Teatr Jerzego Jarockiego niełatwo zdefiniować, bez wahania zamknąć w jakiejś estetyce. W zakresie adaptacji dla inscenizatora kluczowe jest jak podkreślają badacze - twórcze podejście do materii tekstowej ${ }^{10}$, które w ostatecznym rozrachunku nie wykracza daleko poza dzieło literackie i koncepcję świata przedstawionego wykreowaną przez jego autora. Dla reżysera istotną kwestią była rola teatru jako interpretatora tekstu. Chodziło mu o ujawnianie sensów dzieła, których odkrycie może dokonać się jedynie

\footnotetext{
6 Ibidem, s. 93.

7 Ibidem, s. 92.

8 Ibidem, s. 97.

9 Mianem dramatyzacji będę określać przeróbkę powieści na tekst dramatyczny.

10 Zob. B. Guczalska, op. cit., s. 46.
} 
przez zetknięcie utworu literackiego z medium, jakim jest teatr ${ }^{11}$. Adaptując, reżyser dynamizuje tekst, uscenicznia go, ale nie narzuca własnej poetyki, respektuje cudzą formę, dopasowując styl inscenizowania i grę aktorów do wystawianego dzieła ${ }^{12}$.

Jarocki przeobraża prozę w formę dramatyczną tak, by zachować elementy epickie dzieła. „Esencjalizuje” powieść - operacje, jakich dokonuje na tekście, w zasadzie ograniczają się do podstawowego zabiegu redukcji oraz kondensacji treści ${ }^{13}$. Strategia adaptacyjna reżysera wpisuje się w jeden z podstawowych typów opisywanych przez Didiera Plassarda i Patrice’a Pavisa - inscenizację utrwalającą, która skupia się na immanentnej lekturze dzieła ${ }^{14}$, dążąc do wierności pierwowzorowi ${ }^{15}$. Adaptator pozbywa się jednak wielu elementów powieści. W pierwszej części spektaklu, skupionej przede wszystkim wokół „śledztwa” przeprowadzonego przez Witolda i Fuksa, Jarocki decyduje się na usunięcie wielu monologów wewnętrznych Witolda, eliminuje niektóre fragmenty będące relacjami z leniwie toczącego się życia pensjonatu. Rezygnuje z powtarzających się opowieści Fuksa dotyczących problemów w pracy oraz z niektórych fragmentów dotyczących wspomnień Kulki i Leona. Zabiegi te, choć w dużej mierze korzystne (usunięcie elementów rozciągających bieg akcji dynamizuje inscenizację),

11 Zob. J. Jarocki, Ślub z Gombrowiczem, „Teatr” 2004, nr 11-12, s. 4-9.

12 A. Wirth, Teatr Jerzego Jarockiego, cz. II, przeł. D. Borkowska, „Dialog” 1991, nr 2, s. 114.

13 O tych i innych metodach przetworzeń pisali m.in.: Marek Hendrykowski w kontekście adaptacji filmowej (M. Hendrykowski, Współczesna adaptacja filmowa, Poznań 2011), Marta Miłoszewska na płaszczyźnie teatru (M. Miłoszewska, Adaptacja. Skrzynka z narzędziami, Warszawa 2017, s. 41-67); z kolei Ewa Szczęsna szeroko omówiła strategie przetworzeń różnorodnych testów kultury (E. Szczęsna, Twórcza zmiana. Medialne przetworzenia sztuki, [w:] Rejony twórczej zmiany. Tekst. Adaptacja. Medialna re-kreacja, red. B. Pawłowska-Jądrzyk, K. Gołos-Dąbrowska, Warszawa 2019, s. 13-30).

14 P. Pavis, Współczesna inscenizacja, tłum. P. Olkusz, Warszawa 2011, s. 394.

15 P. Pavis definiuje wierność jako iluzję, którą należy wyczytać, zinterpretować i wygrać w sztuce zgodnie z intencjami twórcy, a postawa ta wymaga antycypacji konkretnego, prawidłowego odczytania dzieła, zgodnego z założeniami autora. Kwestię wierności w dyskusjach teatrologicznych omawiano wielokrotnie. Jednak mimo obalenia „doktrynalnego postulatu wiernej lektury”, problem ciągle powraca w związku $\mathrm{z}$ ponawianym pytaniem o granice swobody interpretacji teatralnej. Zob ibidem, s. 393. 
nie pozwalają na ekspozycję w spektaklu jednego z tematów Kosmosu, jakim jest nuda ${ }^{16}$. Pozwalają natomiast na wyeksponowanie problemów najistotniejszych z punktu widzenia scenicznego interpretatora. Drugą część spektaklu stanowi wycieczka w góry, której przewodniczy Wojtys. Jerzy Jarocki, adaptując tę część powieści, rozpoczyna od sceny górskiego pikniku. Rezygnuje z obszernego fragmentu będącego opisem przejażdżki bryczką, wykluczając zarazem szereg refleksji odnarratorskich. Nie oznacza to, że adaptator zupełnie zrezygnował $\mathrm{z}$ wątków pojawiających się w tym fragmencie - część dialogów, która w powieści miała miejsce podczas podróży, w spektaklu pojawia się już podczas posiłku w schronisku (tam też dopiero grupa pod przewodnictwem Leona spotyka siedzącego na głazie, zagubionego księdza). Jarocki znacznie ogranicza wątki związane z Lulusiami i Tolusiami, redukując tym samym materiał literacki związany z pewnego rodzaju trywializacją, „upupianiem” erotyki. Zdecydowany nacisk w tej części spektaklu zostaje położony na postać Leona, pełniącego rolę zarówno przewodnika górskiego, jak i „kapłana” chcącego wtajemniczyć podróżników w „tajemnicę szczytowania”. W tym przypadku adaptator niemal w całości przeniósł na scenę fragmenty powieści związane z kumulującym się napięciem pomiędzy bohaterami: konfrontacje Leona i Witolda (odkrycie przez Wojtysa prawdziwych intencji podróży), spotkanie Witolda z Leną, wieczerzę poprzedzającą „świętowanie rocznicy” oraz sam akt „bergowania”, którego dokonuje Leon. Szczególnie zaakcentowany zostaje więc dziwaczny, początkowo skupiony na celebrowaniu małych przyjemności, ale w efekcie demoniczny erotyzm Leona.

Chęć adaptatora do pozostania blisko intencji autorskich objawia się również w sposobie konstruowania dialogów. Jarocki, jeśli nie używał dosłownych cytatów z dzieł inscenizowanych, parafrazował je (szczególnie w przypadku partii monologowych), zachowując swoisty styl pierwowzoru. Na scenie pojawia się Witold-narrator, który częściowo relacjonuje wydarzenia i to jego perspektywę przyjmuje widz. Nie oznacza to jednak, że powieściowe wypadki są w scenicznej narracji rekonstruowane (co byłoby zresztą „wbrew utworowi”), a Jarocki stworzył z adaptacji „teatr opowieści”,

${ }^{16}$ O „doświadczeniu fatalizmu nudy niekonieczności” w kontekście Kosmosu Gombrowicza zob. B. Pawłowska-Jądrzyk, Sens i chaos w grotesce literackiej, Kraków 2002, s. 158 i nast. 
w którym narrator stanowiłby absolutne centrum spektaklu. Wszak - jak zwraca uwagę Leonard Neuger w rozważaniach dotyczących powieści Witold to niejednoznaczny „narrator nic niewiedzący”. Z jednej strony podmiot jest tylko biernym aktorem, wykonawcą, rodzajem medium (nie tyle myśli, ile „jest myślany”, nie tyle działa, ile jest „działany”), z drugiej dąży do odczytania znaków, które mu się jawią ${ }^{17}$.

W myśl takiego odczytania Witold, grany w spektaklu przez Oskara Hamerskiego, to narrator niby-wiedzący, niby-działający i niby-opowiadający. Wydaje się jakby zagubiony w rzeczywistości spektaklu, nie „chodzi”, ale nagle „znajduje się”, nie działa, ale wykonuje czynności bezwiednie. Przykładem może być sposób pokazania powieszenia Dawidka (kota Leny) przez bohatera-narratora. Witold zauważa (pojawiającego się w uchylonym module scenografii) kota, po czym scena zostaje gwałtownie wyciemniona. Słyszymy głośne miauknięcie, światło ponownie się zapala, a naszym oczom ukazuje się powieszone zwierzę. Witold podsumuje zaistniałą sytuację jedynie słowami „Do kompletu!”. Odbiorca odnosi wrażenie, iż kot powiesił się niemalże sam.

Co ciekawe, rola Witolda jako narratora nie jest równie rozbudowana w obu częściach spektaklu. Nie do końca wiadomo, na ile bohaterowie opowieści Witolda są świadomi jego obecności. Mieszają się dotychczas bez trudu oddzielane przez widza światy i czasy, a na scenie panuje niemal kompletna ciemność (mamy do czynienia jedynie z bladoniebieskim światłem przywodzącym na myśl poświatę księżycową). Witold przestaje być osobą dramatu (bohaterem), pozostaje już niemal tylko scenicznym narratorem, pragnącym zamknąć swoją historię, połączyć szaleństwo apofenii z późniejszymi zdarzeniami: „pielgrzymką” Leona i śmiercią Ludwika. Elementem spajającym różne wątki stają się w końcu usta: Katasi, Leny, Witolda (który przyjmuje od Wojtysa „komunię” z karmelka), martwego męża Leny i księdza.

Kosmos jest powieścią, w której mamy wiele „mówienia o opowiadaniu”"18, niekiedy elementy dialogiczne zlewają się z monologami narratora (m.in.

17 L. Neuger, „Kosmos” Witolda Gombrowicza. Genologiczne podstawy hipotez sensowności, „Teksty Drugie” 1999, nr 6, s. 57-70.

18 J. Jakubowska-Cichoń, Mowa przytaczana w narracjach Marguerite Duras, Kraków 2010, s. 23-26. 
relacjonowanie rozmów z Drozdowskim, konwersacje z Wojtysami podczas posiłków) lub bohaterów. W procesie dramatyzacji Jarocki wyodrębnia tego typu wypowiedzi bohaterów i dialogizuje je:

[Witold o Leonie - przyp. K. G-D.] Nie zawsze „dziwolążył się ze słowostworem", czasem zaczynał po wariacku, a kończył normalnie lub na odwrót - błyszcząca okrągłość jego łysej bani z doczepioną u dołu twarzą, $z$ doczepionymi pince-nez, unosiła się nad stołem jak balon - często wpadał w dobry humor i sypał anegdotami, mat u sień ku, pomaleńku, znasz ten bicykl o trycyklu, co jak icykl wsiadł na bicykl, to był trycykl, hejże ha! Kulka zaś poprawiała mu coś w okolicy ucha albo na kołnierzu ${ }^{19}$.

W owo „dziwolążenie” Leona Jarocki wplata monolog Kulki dotyczący zeszpecenia ust Katasi:

KULKA: Lena, popraw ojcu kołnierzyk... (Lena nie wstając zkrzesła, coś tam poprawia ojcu.)

Ile razy jej mówię: Kata, nie leń się, nie bój się. Idź do chirurga, zoperuj! Jak ty wyglądasz? Idź! Ureguluj sobie ten wygląd. Ale gdzie tam 5 lat od wypadku... LEON: Kulaszka. Co ty tam ciumcialisz? (Wstaje od stotu $i$ idzie do szachownicy.)

KULKA: (do Witolda) Mówiłam, wie pan, że koszta pokryję...

LEON: Matusieńku, pomaleńku... znasz ten bicykl o trycyklu, co jak icykl wsiadł na bicykl, to był trycykl, hejże ha ${ }^{20}$.

Jarocki podchodzi do monologów Witolda na dwa sposoby. Te, które stanowią jego indywidualne refleksje, pozostają najczęściej scenicznymi monologami w skróconej lub sparafrazowanej formie. Inaczej postępuje z elementami prezentacji scenicznej narratora oraz refleksjami dotyczącymi śledztwa, które zostają częściowo zamienione na dialogi z Fuksem (alter ego Witolda). Zabieg ten nie tylko wysuwa na plan pierwszy postać Fuksa, ale również wskazuje na świadome kreowanie Fuksa na sobowtóra narratora:

19 W. Gombrowicz, Kosmos, Kraków 1986, s. 21.

20 J. Jarocki, Kosmos, Teatr Narodowy, 2005, s. 70. [Tekst dramatyzacji.]. 
- Nie dałbym trzech groszy, czy ktoś sięz nas nie nabija.

- Kto?

- Ktoś z nich... Z tych, co byli obecni, jak opowiadałem o wróblu i jakeśmy rozpoznali strzałkę na suficie w stołowym. [...] To jednak nie trzymało się kupy. Komuż by się chciało uprawiać tak skomplikowane żarty? Po co? Któż mógł wiedzieć, że odkryjemy strzałkę i zainteresujemy się nią aż tak bardzo? Nie, to był czysty przypadek - ta pewna, niewielka zresztą, zbieżność między patykiem na nitce a wróblem na drucie. Zgoda, patyk na nitce, tego nie widuje się co dzień... ale przecie ten patyk mógł wisieć z tysiąca przyczyn, niemających nic wspólnego z wróblem, wyolbrzymiliśmy jego znaczenie, ponieważ ukazał się nam u samego kresu naszych poszukiwań jako ich rezultat - naprawdę nie był żadnym rezultatem, był tylko patykiem na nitce... Przypadek zatem? Owszem... ale jakaś skłonność do składności, coś jak gdyby mgliście zahaczającego, dawała się wyczuwać w szeregu tych zdarzeń - powieszony wróbel - powieszone kurczę - strzałka w stołowym - strzałka w naszym pokoju - patyk wiszący na nitce - przebijało się w nich jakieś parcie ku sensowi, jak w szaradach, gdy litery zaczynają zmierzać do ułożenia się w słowo. Jakie słowo? Tak, wydawało się jednak, że wszystko chciałoby sprawować się w myśl jakiejś myśli... Jakiej? Jaka myśl? Czyja myśl? Jeśli była to myśl, to ktoś musiał być za nią - ale kto? Komuż by się chciało? Agdyby... a jeśli Fuks mi wypłatał psikusa, bo ja wiem, z nudów... ale nie, gdzieżby tam Fuks... tyle wysiłku wkładać w głupi figiel... nie, to też nie trzymało się kupy. Przypadek zatem? Byłbym się zgodził może w końcu, że czysty przypadek, gdyby nie inna anormalność, która poniekąd miała skłonność do zahaczenia o tę anormalność... gdyby ta dziwność z patykiem nie była poparta inną dziwnością, o której wolałem nie mówić Fuksowi.

- Katasia.

$[\ldots]$

- Co? - zapytałem.

- Jak się ma taki dzióbek zmanierowany... - zamyślił się i dodał chytrze. - Swój do swego po swoje!.... ${ }^{21}$.

Co Jarocki dramatyzuje w następujący sposób:

WITOLD: Zgoda patyk na nitce - tego nie widuje się co dzień... ale...

${ }^{21}$ W. Gombrowicz, op. cit., s. 30. 
FUKS: Ktoś, nie dałbym trzech groszy, czy ktoś się z nas nie nabija...

WITOLD: Kto? Komu by się chciało?

FUKS: Pomyśl!

WITOLD: To się nie trzyma kupy. Ten patyk może wisieć z tysiąca przyczyn. Jest tylko patykiem na nitce i patyk wiszący na nitce...

FUKS: Powieszony patyk, powieszony wróbel, powieszone kurczaki, strzałki. Strzałka w stołowym, strzałka u nas w pokoju...

WITOLD: Niby przebija się jakieś parcie ku sensowi... ale...

FUKS: Jak w szaradach, (Rysuje palcem na podłodze jakieś litery.) gdy litery zaczynają zmierzać do ułożenia się w słowo...

WITOLD: Jakie słowo?

FUKS: W myśl jakiejś myśli...

WITOLD: Jakiej myśli? Czyjej myśli?

FUKS: Jeśli jest to myśl, to ktoś musiał być za nią.

WITOLD: Kto? Komu by się chciało?

FUKS: Bo ja wiem... bo ja wiem... Co jak się ma taki dziubek zmanierowany? Mnie od razu to jej... to, co ona ma z ustami, wydało się... ale... i tak, i siak... w tę i we w tę... Jak uważasz?

WITOLD: Katasia ${ }^{22}$.

Z kolei niewielka liczba osobowych form czasowników, jaka cechuje niektóre fragmenty powieści, pozwala zrytmizować pewne sceny, a nawet przekształcić fragmenty „dziwolążeń” Leona (i nie tylko) w pieśni chóru mające w rzeczywistości formę przyśpiewek skandowanych podczas ludycznej zabawy w górach:

(Zza kulis stychać rytmiczny tupot i skandowanie. Ogólna zabawa. Po chwili $z$ lewej strony pojawia się rozbawiony korowód młodzieży: Luluś, Lulusia, Fuks, Lena, Toluś, Jadeczka i Ksiądz. Towarzystwo śpiewając, mija siedzącego przy stole Witolda i Kulkę, po czym znika w przeciwnej kulisie.)

CHÓR:

(śpiew)

Wynurzy się knurem z nory,

Snując gędźby nad gędźbami

Toluś, Toluś

Razem z nami

Plecak jej się w pupkę wrzyna

22 J. Jarocki, op. cit., s. 74. 
Dusza kic na całe życie

A on teraz miesiączkuje

Siebie wącha nic nie czuje ${ }^{23}$.

Ponadto adaptator zamienia na dialogi również te elementy narracji, które wypełnione są rytmem charakterystycznych dla twórczości Gombrowicza powtórzeń $^{24}$. Jarocki dialogizuje i zarazem rytmizuje opowieść Witolda, czym potęguje wrażenie zapętlania się, daremnego dążenia do odnalezienia sensu przez bohaterów powieści. Zostaje to wyeksponowane już na początku spektaklu, kiedy bohater-narrator wraz z Fuksem wędrują w poszukiwaniu noclegu i w rytm dialogu maszerują po linii okręgu:

WITOLD: Gorąco.

FUKS: Gorąco... No to co? Idziemy?

FUKS: Idziemy.

WITOLD: Raz dwa, raz dwa, raz dwa, raz dwa...

FUKS: Widzisz?

WITOLD: Co?

FUKS: Świerki...

WITOLD: Świerki...

FUKS: Sosny...

WITOLD: Sosny, płoty...

FUKS: Domki...

WITOLD: Domki, zielsko, trawa, rów, ziemia, grządki, pola...

Raz dwa - raz dwa, raz dwa, raz dwa, raz dwa...25.

${ }^{23}$ J. Jarocki, ibidem, s. 111.

24 Zob. A. Czabanowska-Wróbel, Kosmos powtórzeń Witolda Gombrowicza, „Teksty Drugie" 2005, nr 3, s. 79-90.

25 J. Jarocki, op. cit., s. 64. Jest to dialogizacja fragmentu pierwszej sceny: „Pot, idzie Fuks, ja za nim, nogawki, obcasy, piach, wleczemy się, wleczemy, ziemia, koleiny, gruda, błyski ze szklistych kamyczków, blask, upał brzęczy, gorąco drgające, czarno od słońca, domki, płoty, pola, lasy, ta droga, ten marsz, skąd, jak, dużo by gadać [...]. Idziemy więc, nogawki, obcasy w piachu, droga i gorąc, patrzę w dół, ziemia i piasek, iskrzą się kamyczki, raz, dwa, raz, dwa, nogawki, obcasy, pot, śpik w oczach niewyspanych z pociągu i nic prócz kroczenia tego oddolnego. Stanął.” (zob. W. Gombrowicz, op. cit., s. 5). 
Opowiadanie, czy raczej dopowiadanie, akcji scenicznej ma również charakter metatekstowy, co jest naturalną konsekwencją uwzględnienia $\mathrm{w}$ adaptacji rozważań dotyczących opowiadania ex post. Jednak w sposobie kształtowania dialogów scenicznych Jarocki podejmuje próbę oddania „chaosu rodzącej się chwili”, wykorzystując performatywność medium. Ekwiwalentem owego „bełkotu” w dramatyzacji Jarockiego wydaje się stosowanie opóźnień reakcji odbiorczej w dialogach (1.) oraz nakładanie się na siebie wypowiedzi postaci (2.):

1. FUKS: Tam. Sterczy coś.

WITOLD: Niewyraźne.

FUKS: Wisi. Powieszone.

WITOLD: Chce mi się spać. Tyle godzin w pociągu.

FUKS: Wróbel.

WITOLD: Aha.

[...]

FUKS: Tu także mają pokoje do wynajęcia.

WITOLD: Aha... leje się ze mnie, ale skwar...

(Patrzy na domek.)

Mizerne to... oszczędnościowe ${ }^{26}$.

2. WITOLD: Co za zbieg okoliczności, te „kombinacje”.

FUKS: O co ci chodzi?

WITOLD: Te „kombinacje” z żołnierzami Ludwika.

26 J. Jarocki, op. cit., s. 65-66. Fragment powieści wygląda następująco:

„Tam między gałązkami coś tkwiło - coś sterczało odrębnego i obcego, choć niewyraźnego... i temu przyglądał się też mój kompan.

- Wróbel.

- Acha.

[...]

- Tu także mają pokoje do wynajęcia. Spojrzałem. Ogródek. Dom w ogródku, za parkanem, bez ozdób, balkonów, nudne i mizerne, oszczędnościowe, z gankiem skąpym, sterczące, z drzewa, zakopiańskie, z dwoma rzędami okien, parter i piętro po pięć, co zaś do ogródka, to kilka karłowatych drzewek, trochę bratków mdlejących na grządkach, parę żwirowanych ścieżek. [...] Ja też byłem gotów zajść, zobaczyć, choć poprzednio minęliśmy kilka takich tabliczek, nie zwracając na nie uwagi - ale lało się ze mnie. Skwar.” (zob. W. Gombrowicz, op. cit., s. 6). 
KULKA: Leona całe życie musiałam doglądać, pan nie ma pojęcia, angina, reumatyzm, kamienie w wątrobie... A to, a tamto, wiecznie coś, ja wprost nie wiem, jak by ten człowiek beze mnie...

WITOLD: To prawie nasz - nasze kombinacje...

KULKA: (Na chwile pojawia się w drzwiach.) Kawę mu do łóżka, całe życie... WITOLD: Cóż łatwiejszego niż kombinacje, gdy wokół rój, szum, rzeka drobiazgów i szczegółów.

KULKA: (Wraca.) Zawsze stałych lokatorów miałam na karku... a lokatorzy!... panowie nie mają pojęcia, a to temu jeść, temu pościel, temu lewatywa, tamten z piecykiem, o piecyk... W Drohobyczu mieliśmy ładny parter willi z wygodami i wynajmowali my pokoje z utrzymaniem lub bez. Nieraz i sześciu stołowników „z miasta”, przeważnie starszych z chorobami. A to temu papkę, temu zupkę, a to nic kwaśnego!

WITOLD: A ręce, nasze ręce „Zaroiły” się dlatego, że osa, z powodu osy, ale któż może zaręczyć, że osa nie była tylko pretekstem dla wezbrania rąk, w związku z jej rączką... podwójny sens... ${ }^{27}$.

W pierwszym z przytoczonych fragmentów to, co „tu i teraz”, przenika się ze wspomnieniami z podróży pociągiem. Mamy więc do czynienia z zaznaczeniem subiektywnego punktu widzenia ${ }^{28}$, przeformułowaniem powieściowego „strumienia świadomości”. Druga z cytowanych scen stanowi parafrazę rozmyślań Witolda ${ }^{29}$ na temat powiązania „roju rąk” domowników (wymachujących podczas kolacji na skutek pojawienia się muchy) $\mathrm{z}$ anegdotą Ludwika dotyczącą kombinatorycznych obliczeń. Dialog ten przeplata się z monologiem Kulki, który również stanowi kompilację jej wypowiedzi rozproszonych w powieści.

\section{TROPY INTERPRETACYJNE OBECNE W SPEKTAKLU}

Jarocki przy okazji każdej adaptacji gruntownie studiował wszystkie dostępne mu opracowania literaturoznawcze, czego wymagał również od swoich aktorów ${ }^{30}$. Ślady jego lektur są widoczne w spektaklach, co nie oznacza,

27 J. Jarocki, op. cit., s. 78.

28 Zob. J. Jarzębski, Gra w Gombrowicza, Warszawa 1982, s. 447.

29 Zob. W. Gombrowicz, op. cit., s. 33.

30 Przy realizacji Kosmosu reżyser do współpracy (nie po raz pierwszy) zaprosił Jerzego Jarzębskiego, obecnego podczas prób do spektaklu. Ponadto, przed pierwszą 
że mamy do czynienia z inscenizacjami w pełni interpretacyjnymi ${ }^{31}$. W przypadku Kosmosu Jarocki nie przyjmuje jednej wybranej interpretacji, ale zdaje się czerpać po trochu z kilku odczytańn ${ }^{32}$.

Istotnym tropem dla tego spektaklu wydaje się koncepcja dualizmu Kosmosu. „Zgrabny dualizm” to trop uspójniający świat powieści Gombrowicza i owej dwoistości reżyser używa jako ramy ${ }^{33}$. Jarzębski wychodzi w tej interpretacji powieści od postaci Katasi, której zdeformowane na skutek wypadku usta są jednocześnie skórą i śluzówką, wnętrzem i zewnętrzem, sferą publiczną i prywatną, tym, co dozwolone i zabronione. Podwójność w przedstawieniu sygnalizuje scenografia wykreowana przez Jerzego Juka-Kowarskiego. Po pierwsze, przestrzeń uformowana na kształt graniastosłupa o ścianach przypominających papier milimetrowy (il. 1) ma swój awers i rewers. Na białym tle rozgrywa się wszystko to, co związane z próbą kreowania rzeczywistości, oraz to, co oficjalne. Zaś po drugiej stronie białej konstrukcji odkrywane jest to, co wstydliwe, prywatne, nieoficjalne (il. 3 i 6). Podwójność zostaje zasugerowana również przez sam podział sceny. Wysokość trójkąta stanowiącego scenę wyznacza przestrzenie bohaterów, którzy dokonują konfrontacji, „przeglądają” się w swoich sobowtórach (il. 1 i 2). Dualizm powieściowy zostaje wyeksponowany także poprzez kolorystykę i grę świateł. W spektaklu kontrastują ze sobą jasność i ciemność. Scenograf, aby zwizualizować oksymoron „wszystko czarne od słońca”, używa kontrastu: ciemności wyłaniające się spoza białej konstrukcji stanowią przeciwwagę dla jasnej przestrzeni sceny.

W tym kontekście istotne wydaje się również operowanie światłem w przestrzeni świata przedstawionego spektaklu. Sceny intymne (monologi Witolda, rozmyślania, podchody, rewizja u Katasi, podglądanie Wojtysów), nocne (kulminacyjna scena „bergowania”) lub potencjalnie budzące grozę (scena uśmiercania kota, odnalezienie powieszonego Ludwika, eksces z palcem Witolda w ustach księdza) skąpane są w ciemności niemal całkowicie.

z nich, został zorganizowany wykład gombrowiczologa dla twórców spektaklu (zob. E. Konieczna, Jerzy Jarocki. Biografia, Kraków 2018, s. 369).

31 Zob. A. Duda, Reżyserskie strategie inscenizacji dzieła literackiego, Toruń 2017, s. $53-74$.

${ }^{32}$ Zob. B. Guczalska, Znaki chaosu czy sensu?, „Didaskalia” 2005, nr 70, s. 54.

33 J. Jarzębski, Natura i teatr..., s. 89. 


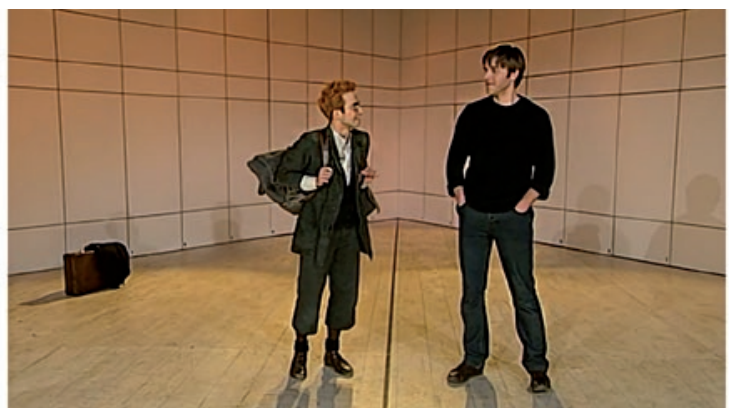

Il. 1. Pierwsza scena spektaklu - Witold spotyka Fuksa. Jerzy Jarocki, Kosmos, Teatr Telewizji, 2006. Kadr z nagrania spektaklu

Jedyne źródło świtała to słaba niebieskawa smuga reflektora lub latarki (il. 3 i 6). Niekiedy źródło ciepłego światła usytuowane zostaje z daleka od obiektów, przestrzeń rozjaśniona jest równomiernie. Światło przypomina sztuczną jasność pochodzącą z ogromnych świetlówek, która „spłaszcza” przedmioty znajdujące się na tle podobnej do układu współrzędnych scenografii. Dzięki temu powstaje wrażenie, że mają one jakieś konkretne współrzędne.

Kolejną drogą odczytania powieści zasugerowaną w spektaklu może być trop erotyczny czy też autoerotyczny, rozważany m.in. przez Aleksandrę Okopień-Sławińską ${ }^{34}$ i Jerzego Jarzębskiego ${ }^{35}$. Ekspresyjne monologi Witolda dotyczące niemożności wejścia w intymną relację z Leną (a nawet niemożliwości samego pragnienia, ponieważ Witoldowi „nie chce się chcieć”, nie ma on ochoty kochać), obecne w pierwszym akcie, płynnie łączą się w drugiej części spektaklu z ceremonią świętowania rocznicy Leonowego pozamałżeńskiego spełnienia. Wraz ze zmianą dotychczasowego głównego wątku fabularnego pojawiają się również nowe rekwizyty. Dominują te o kształtach fallicznych, np. cygaro, kłoda, której dosiada Leon (il. 2) czy podłużny wysoki kamień. Ponadto niezwykle istotną scenę drugiego aktu stanowi rytuał odprawiany przez Wojtysa, podczas którego m.in. udziela Witoldowi

34 Zob. A. Okopień-Sławińska, Wielkie bergowanie, czyli hipoteza jedności „Kosmosu”, [w:] Gombrowicz i krytycy, wybór i oprac. Z. Łapiński, Kraków 1984, s. 693-706.

35 Zob. J. Jarzębski, Dwanaście wersji „Kosmosu”, [w:] Natura i teatr..., s. 123. 


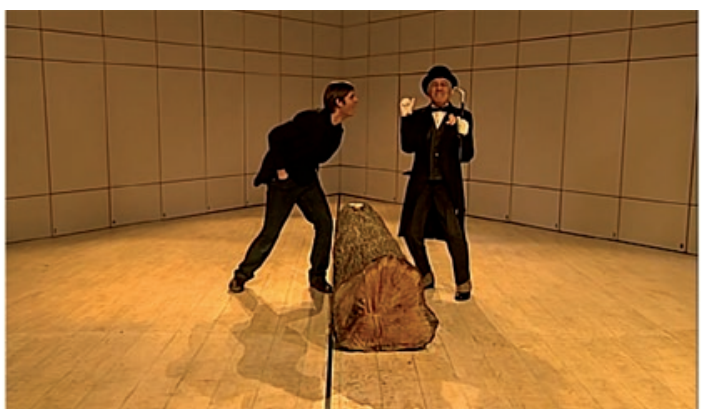

Il. 2. Jerzy Jarocki, Kosmos, Teatr Telewizji, 2006. Kadr z nagrania spektaklu

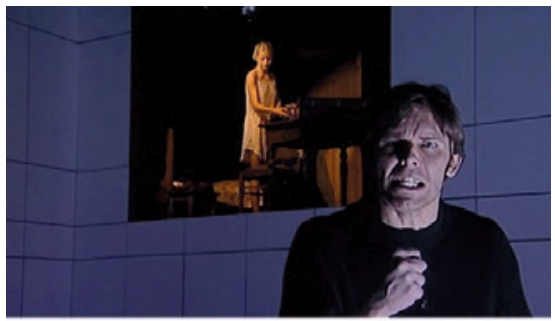

Il. 3. Podglądanie Leny przez Witolda. Jerzy Jarocki, Kosmos, Teatr Telewizji, 2006. Kadr z nagrania spektaklu

„komunii” z karmelka (il. 4), czy też - wznosząc ku górze jajko - rozkoszuje się marzeniem o stosunku pozamałżeńskim (il. 5).

\section{PRZESTRZEŃ KOSMOSU}

\section{PLASZCZYZNY JEJ INTERPRETACJI}

Twórcy scenografii do spektakli Jarockiego często naprowadzają odbiorcę na ścieżki interpretacyjne za pomocą „wielkich metafor” scenograficznych. W przypadku Błądzenia, do którego scenografię stworzył Andrzej Witkowski, taką metaforą wizualną była okrągła scena umożliwiająca zobrazowanie ciągłego zapętlania się postaci, zaś w Grzebaniu scenografia, której oś stanowi wykopany grób artysty, miała być metaforą pamięci zbiorowej Polaków o rodzimych artystach. Projekty scenograficzne autorstwa Jerzego Juka-Kowarskiego, współpracującego z Jarockim już od lat siedemdziesiątych, wpisują się, jak pisze Ewa Dąbek-Derda, w teorię urbanistyczną 


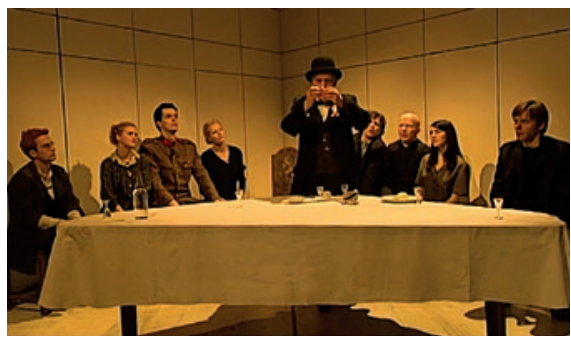

Il. 4. „Czarna msza” Leona - moment, w którym Leon naśladując gest liturgiczny uniesienia Ciała Chrystusa, demonstruje za pomoca wydmuszki zdradę matżeńską. Jerzy Jarocki, Kosmos, Teatr Telewizji, 2006. Kadr z nagrania spektaklu

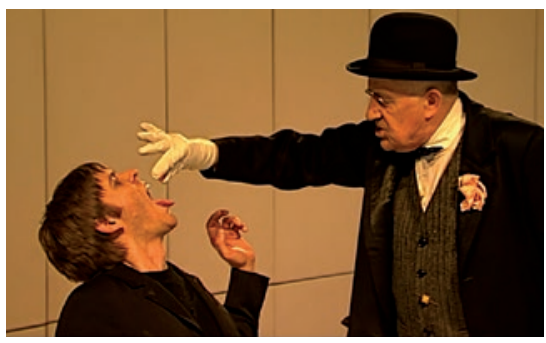

Il. 5. Komunia z karmelków. Jerzy Jarocki, Kosmos, Teatr Telewizji, 2006. Kadr z nagrania spektaklu

Formy Otwartej Oskara Hansena, według której przestrzeń powinna pełnić funkcję poznawczą ${ }^{36}$. Dla scenografa teatr był narzędziem poznania, dzięki któremu ujawnia się kondycja człowieka ${ }^{37}$. Najważniejszym zadaniem scenografii stało się uczytelnienie świata przedstawionego, miała ona być przede wszystkim tłem dla wszelkich pojawiających się na scenie postaci i obiektów. Przestrzeń sceniczna Kowarskiego, ze względu na swoją ascetyczność, uwypukla performatywny charakter teatru, pozwala na ekspozycję aktora i przyjrzenie się postaci. Konstrukcje scenograficzne mają służyć zarówno samemu dziełu, jak i jego rozumieniu ${ }^{38}$.

W przypadku Kosmosu status scenografii nie jest do końca oczywisty. Scena teoretycznie zostaje oddzielona od sali, ma kształt otwartego graniastosłupa o trójkątnej podstawie. Można odczytać ją jako abstrakcyjną przestrzeń zamkniętą, dystansującą widza, bądź wręcz przeciwnie, jako fragment wykroju kuli odpowiadający 1/8 bryły, której sferyczna część pozostaje dla obserwatora niewidoczna, gdyż został on w ową kulę wpisany. Scenografię

${ }^{36}$ Właściwie Zofii i Oskara Hansenów, zob. Tożsamość. 100 lat polskiej architektury, red. B. Stelmach, K. Andrzejewska-Batko, Warszawa 2019, s. 195.

${ }^{37}$ E. Dąbek-Derda, Teatralne przestrzenie Jerzego Jarockiego, [w:] Odsłony wspótczesnej scenografii. Problemy - Sylwetki - Rozmowy, red. K. Fazan, A. Marszałek, J. Rożek-Sieraczyńska, Kraków 2016, s. 198.

38 Ibidem, s. 199. 
Kowarskiego można interpretować na różne sposoby. Zwrócę tu uwagę na kilka kwestii, które wydają się szczególnie istotne w omawianym kontekście.

\section{GEOMETRYCZNA PRZESTRZEŃ I PROBLEM CHAOSU}

Przestrzeń sceniczna zamyka się w graniastosłupie o podstawie trójkąta prostokątnego, którego - jak się wydaje - najdłuższy bok to brzeg sceny. Wysokość trójkąta sceny zostaje poprowadzona od podstawy do wierzchołka oznaczanego cyfrą „0”, a każda z kolejnych linii pionowych poprowadzonych na ścianach zostaje u styku z podłogą oznaczona kolejnymi cyframi (il. 1). Przywodzi to na myśl układ współrzędnych wyznaczający punkty nie tylko na płaszczyźnie, ale i w przestrzeni. Istotną funkcję pełnić będzie „0” - to punkt startowy wielu scen (w tym miejscu stoi Fuks, gdy spotyka go Witold, tam też grupa górskich wycieczkowiczów zobaczy księdza), ale również miejsce kulminacji (w tym punkcie przy trójkątnym stole stoi Ludwik, kiedy celebruje swoje święto) (il.5); tam też w końcu znajduje się ogromy głaz, za którym Leon finalizuje pielgrzymkę, „bergując”). Ponadto wysokość poprowadzona z wierzchołka (punktu „0”) na podstawę trójkąta sceny tworzy kształt przypominający strzałkę. Poza aluzją do strzałek Witolda i Fuksa, wskazuje na wierzchołek trójkąta mogący być jednocześnie środkiem sfery (jeśli interpretować scenę otwartą na widownię jako wycinek kuli).

Geometryczna przestrzeń stanie się „narzędziem”, przestrzenią, na której ma się stwarzać rzeczywistość powieści. Dwie ściany konstrukcji scenograficznej złożone są częściowo z ruchomych, ponumerowanych modułów, za którymi kryją się kolejne pomieszczenia. Ta konstrukcja to trójwymiarowy układ współrzędnych, na nim umieszczone zostaną dane na temat rzeczywistości i ślady domniemanej zbrodni: wróbel, patyk, dyszel itd. Układ współrzędnych jest narzędziem służącym bohaterom do porządkowania rzeczywistości, do mierzenia odległości, układania danych i pozyskiwania wyników. Ogromny trójwymiarowy układ nie sugeruje wprost bezmiaru chaosu - chaosu, który w świetle powieści Gombrowicza może wydać się ideą utopijną ${ }^{39}$. Przeciwnie, kojarzy się z twardą, matematyczną logiką, uosabia pragnienie uporządkowania. Fakt występowania ciemnych,

39 Nasuwa się w tym kontekście pytanie: „Czy/jak wobec tak intensywnego »napięcia semantyzacji« w świecie przedstawionym Kosmosu Gombrowicza możliwe są chaos i niedorzeczność?”. Zob. B. Pawłowska-Jądrzyk, Sens i chaos..., s. 145 i nast. 
tajemniczych i nieuporządkowanych przestrzeni poza białą, kratkowaną fasadą świadczy o niewystarczalności geometrii euklidesowej do opisu rzeczywistości. Co więcej, nasuwa się podejrzenie, że sceniczny trójkąt, podstawa graniastosłupa, to nie euklidesowy trójkąt równoramienny, ale na siłę porządkowany fragment większej formy - ciemnej, niezrozumiałej i być może niemierzalnej.

\section{METAFORA MAPY, UKRYTE KŁĄCZA I PROBLEM NIESKOŃCZONOŚCI}

Z drugiej strony scenografię Kosmosu odbierać możemy jako „realizację metafory” mapy. Pusta przestrzeń jest powoli zapełniana przez „kartografów" - Witolda i Fuksa, którzy w swoich poszukiwaniach posługują się zarówno mapą, jak i busolą. Umieszczają na „układzie współrzędnych” blaszkę, tekturkę, robaka, dyszel, w konkretnych miejscach układu wisi patyk, wróbel i kot. Scenografia może być więc interpretowana jako płótno służące do symulowania rzeczywistości. Jeśli iść tą drogą skojarzeniową, otwarcie się poszczególnych modułów „mapy” może pociągać za sobą wizualizację koncepcji „kłącza”:

Mapa jest otwarta, daje się połączyć we wszystkich swych wymiarach, daje się zdemontować, odwrócić, podatna jest na stałe modyfikacje. Może zostać rozdarta, odwrócona, może zostać przystosowana do montażu każdego typu [...], kłącze pozostaje w związku z mapą, która musi zostać wytworzona, skonstruowana w taki sposób, by dać się zdemontować, połączyć, odwrócić, zmodyfikować, objąć wielorakie wejścia i wyjścia oraz linie ujścia ${ }^{40}$.

Takie odczytanie scenografii Juka-Kowarskiego znajduje motywację w samej powieści. Narrator bowiem używa metafory kartograficznej do opisu swojego postrzegania ${ }^{41}$. Przestrzeń mapy po otwarciu ukazuje swoją „nieskończoność” - ciemne zakamarki są rozjaśniane przez punktowe światła, co pozwala odkryć ogrom elementów budzących kolejne skojarzenia. Możliwości otwarcia jest dużo, każda z komór może kryć wiele nowych

40 G. Deleuze, F. Guattari, Kłącze, przeł. B. Banasiak, „Colloquia Communia” 1988, nr 1-3, s. 221-234.

${ }^{41}$ Zob. W. Gombrowicz, op. cit., s. 14-15 (,jedno było »względem drugiego« - jak na mapie - jak na mapie jedno miasto względem drugiego miasta, w ogóle mapa wmieszała mi się do głowy, mapa nieba czy mapa zwykła z miastami”). 
danych, a każda z nich, z uwagi na głęboką ciemność, zdaje się nieskończona (Il. 3 i 6$)^{42}$.

\section{SWOISTOŚĆ ŚWIATA PRZEDSTAWIONEGO SPEKTAKLU I JEGO IMPLIKACJE EZGYSTENCJALISTYCZNE}

„Męcząco niejasny i napięty jest mój stosunek do egzystencjalizmu. Sam go uprawiam, a jednak nie wierzę mu"43 - deklarował Gombrowicz na kartach Przewodnika po filozofii w sześć godzin i kwadrans. Właśnie z tropami egzystencjalnymi można również łączyć relacje, w jakie niekiedy wchodzą postaci z przestrzenią sceniczną. Znakiem teatralnym naprowadzającym na tego rodzaju odczytanie jest ubrany w ciemny strój Witold. Strój bohatera-narratora radykalnie różni się od kostiumu Fuksa, mającego nawiązywać do ubioru międzywojennych taterników. Można rzec, że sceniczny przewodnik, który wraz z Fuksem usiłuje kreślić, projektować świat na przestrzennej osi (dobitniej może niż w powieści), „pracuje nad esencją, by stworzyć egzystencję"44. Jarocki, świadom filozoficznych dróg recepcji powieści, dzięki partiom monologowym Witolda eksponuje w swojej adaptacji kwestię niemożności percepcyjnej i problemu oceny rzeczywistości ex post, co wiąże się z subiektywizacją ${ }^{45}$. Refleksja nad opowiadaniem tego typu ma nie tylko charakter autotematyczny, ale również nasuwa skojarzenia z myślą

${ }^{42}$ Metafory labiryntu, mapy i kłącza są stosowane w refleksji nad samą powieścią. Zob.: W. Karpiński, Gombrowiczowska przestrzeń, [w:] Gombrowicz i krytycy, Kraków 1984, s. 171-184; T. Zielke, Powierzchnie Gombrowicza. „Tancerz mecenasa Kraykowskiego" i perwersja, „Twórczość” 2012, nr 10, s. 96. W opozycji do koncepcji Kosmosu jako dzieła postmodernistycznego staje Dominik Sulej: „Powierzchnia Kosmosu jest labiryntem ukrywającym swoje wnętrze (ono jest źródłem prawa i mapą), nie stanowi zatem analogonu sieci-tekstu postmodernistycznego". Zob. D. Sulej, „Kosmos” jako gabinet luster. Psychomachia Witolda Gombrowicza, Kraków 2015, s. 50.

${ }^{43}$ W. Gombrowicz, Przewodnik po filozofii w sześć godzin i kwadrans, Kraków 2018, s. 82.

44 A. Gall, Humanizm performatywny. Polemika $z$ filozofia w praktyce literackiej Witolda Gombrowicza, Kraków 2011, s. 492.

45 Zob. rozważania o egzystencjalizmie jako współczesnym subiektywizmie [w:] W. Gombrowicz, op. cit., s. 92. 
Sartre'a ${ }^{46}$. Dyskusja ta zostaje finalnie skomentowana przez Fuksa (łączonego przez badaczy z postacią francuskiego filozofa) słowami będącymi parafrazą powieściowego monologu Witolda ${ }^{47}$ :

WITOLD: To był przypadek! Ta strzałka, wtedy przy kolacji nie była wcale najważniejsza. Wszystko było równorzędne, gazeta, fotografie, szachy wszystko - składało się na tamtą chwilę. To dzisiaj, opowiadając ex post, wysuwamy ją na czoło.

FUKS: Expost! Ja nie jestem ex post - ja jestem tu... i teraz! A jak opowiadać nie expost?

Ten krótki dialog ma również charakter metateatralny, w końcu poza opowieścią Witolda-narratora oglądamy zdarzenia na scenie „tu i teraz”48. Odniesieniem do myśli Sartre’a może być sama przestrzeń. Jest sterylna, jakby celowo pozbawiona nadmiaru przedmiotów, „niezorganizowanego konkretu" wpływającego na świadomość ${ }^{49}$. Kiedy Witold z Fuksem zbliżają się do ścian „trójwymiarowego wykresu”, za którym kryje się rzeczywistość poza polem ich projekcji, być może jakaś „prawda”, od nadmiaru rzeczy bohaterów mdli, zaczyna „śmierdzieć szczyną”.

Kiedy wychodzą poza białą ścianę, odnajdują w pokoju Katasi „grzebyk brudny, wyszczerbiony”, „lusterko zatłuszczone”; można odnieść wrażenie, że jak gdyby „mdliło” ich na widok nadmiaru przedmiotów, które nie dają się łatwo wpisać w śledztwo. Interpretacja wizyty w pokoju Katasi, uwzględniająca aluzyjne odniesienie do Mdłości Sartre’a, pojawia się w refleksji

46 Zob. J.P. Sartre, Egzystencjalizm jest humanizmem, tłum. J. Krajewski, Warszawa 1998, s. 67-70.

47 Zob. W. Gombrowicz, Kosmos..., s. 24.

${ }^{48}$ Nie jest to jedyna wypowiedź o charakterze metateatralnym w spektaklu. Jedno z początkowych zdań w dramatyzacji Jarockiego to zwrot Witolda i Fuksa do widzów, będący parafrazą pierwszego zdania powieści: „WITOLD: Opowiemy wam inną historię, dziwniejszą".

49 Pusta przestrzeń sceniczna, którą tak usilnie próbują zapełnić Witold i Fuks, związana jest również z obecnym w powieści tematem nudy jako odmiany „bólu istnienia”. Zob.: B. Pawłowska-Jądrzyk, op. cit., s. 158-159; B. Sienkiewicz, Nuda i świadomość w powieści inteligenckiej, [w:] Nuda w kulturze, red. P. Czapliński, P. Śliwiński, Poznań 1999, s. 162. 


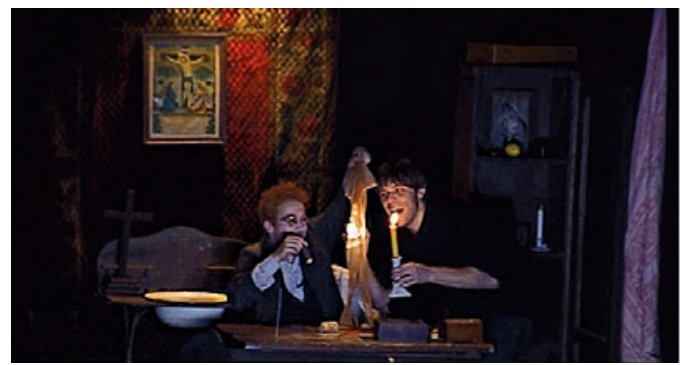

Il. 6. Rewizja w pokoju Katasi. Jerzy Jarocki, Kosmos, Teatr Telewizji, 2006. Kadr z nagrania spektaklu

literaturoznawczo-filozoficznej Alfreda Galla, według którego: „zarówno uduszenie kota, jak i próba eksplikacji prowadzą do odruchu wymiotnego" ${ }^{\text {. }}$. Na takie odczytanie motywów wizualnych pozwala również fakt, że ogromny wpływ na powtórną refleksję Jarockiego nad twórczością Gombrowicza miała lektura książki Czarny nurt. Gombrowicz, świat, literatura Michała Pawła Markowskiego ${ }^{51}$, której „myślowe ślady” odnoszące się do Sartre’a również są widoczne w spektaklu ${ }^{52}$. Jarocki przechwytuje więc i realizuje opisywany szeroko przez badaczy trop krytyki egzystencjalizmu obecny w twórczości Gombrowicza (m.in. w Dziennikach i Operetce czy Kursie filozofii) ${ }^{53}$.

Kosmos, mimo że jest niebywale trudnym materiałem do zaadaptowania, stał się podstawą kilku polskich inscenizacji ${ }^{54}$. Twórcy obierali ku temu różne drogi: Paweł Miśkiewicz zdecydował się na połączenie elementów Kosmosu

50 A. Gall, op. cit., s. 306.

${ }^{51}$ A. Litak, Czytanie genetyczne, „Teatr” 2018, nr 2, http://www.teatr-pismo.pl/ czytelnia/1945/czytanie_genetyczne/ [dostęp 20.03.2021].

${ }_{52}$ Zob. M.P. Markowski, Czarny nurt. Gombrowicz, świat, literatura, Kraków 2004, s. 358.

53 A. Gall, op. cit., s. 492.

54 Szczegółową analizę filmowej adaptacji Kosmosu (reż. Andrzej Żuławski) przeprowadziła Magdalena Romanowska w artykule Między przekładem a parafrazą. „Kosmos” Andrzeja Żuławskiego wobec powieści Witolda Gombrowicza. Zob. Rejony 
z fragmentami innych utworów Gombrowicza (Operetki i Historii); Krzysztof Kopka, stworzył na podstawie powieści monodram (Teatr Dramatyczny im. Jerzego Szaniawskiego w Wałbrzychu, 2001); zaś Krzysztof Garbaczewski potraktował fabułę powieści jako surrealistyczny sen Witolda (Narodowy Stary Teatr im. Heleny Modrzejewskiej, 2016). Niezależnie od obranej metody, adaptatorzy chcąc uczynić $\mathrm{z}$ dramatyzacji spójny konstrukt, w zasadzie zmuszeni są do wykorzystania elementów narracji. Gdy przyjrzymy się bliżej dokonanym przez Jarockiego „operacjom na powieści”, okaże się, że redukuje on część monologów Witolda, korzystając tylko z nielicznych fragmentów utworu będących opisem świata przedstawionego. Ogranicza w ten sposób wszelkie retardacje obecne w pierwowzorze literackim. Niektóre opowieści Witolda dramatyzuje, wyłuskuje z nich sceny dialogowe, a co za tym idzie, eksponuje napięcia między bohaterami. Reżyser, adaptując Kosmos, nie kształtuje go na wzór utworów scenicznych Gombrowicza, czerpiącego z dramatu klasycznego. Pisze scenariusz spektaklu, eksponując absurdalność relacji międzyludzkich zaprezentowanych w twórczości autora Ferdydurke. Zbliża formę tekstową do dramatu epickiego, dzięki czemu widz odnosi wrażenie, że ogląda inscenizację powieści, nie zaś dramatu z niej stworzonego. Wrażenie to jest jednak iluzoryczne, ponieważ w rzeczywistości narracja - choć obecna - nie dominuje, a jedynie dopełnia akcję sceniczną.

\section{Bibliografia}

Anna R. Burzyńska, Ściśle wyznaczona nieskończoność, „Tygodnik Powszechny” 2005, nr 46.

Anna Czabanowska-Wróbel, Kosmos powtórzeń Witolda Gombrowicza, „Teksty Drugie” 2005, nr 3 .

Ewa Dąbek-Derda, Teatralne przestrzenie Jerzego Jarockiego, [w:] Odsłony współczesnej scenografii. Problemy - Sylwetki - Rozmowy, red. K. Fazan, A. Marszałek, J. Rożek-Sieraczyńska, Wydawnictwo UJ, Kraków 2016.

Gilles Deleuze, Félix Guattari, Kłącze, przeł. B. Banasiak, „Colloquia Communia” 1988, nr 1-3.

Joanna Derkaczew, Czarny karnawat Gombrowicza. „Kosmos” w Teatrze Narodowym, „Gazeta Wyborcza” 2005, nr 245.

twórczej zmiany. Tekst. Adaptacja. Medialna re-kreacja, red. B. Pawłowska-Jądrzyk, K. Gołos-Dąbrowska, Warszawa 2019, s. 207-232. 
Artur Duda, Reżyserskie strategie inscenizacji dzieła literackiego, Wydawnictwo Naukowe UMK, Toruń 2017.

Małgorzata Dziewulska, Paradoks Jarockiego, „Dwutygodnik” 2012, nr 93.

Sylwia Frołow, Jerzy Jarocki, Polska szkoła interpretacji Rosji, „Nowaja Polsza” 2006, nr 7-8.

Alfred Gall, Humanizm performatywny. Polemika z filozofia w praktyce literackiej Witolda Gombrowicza, Universitas, Kraków 2011.

Gombrowicz i krytycy, wybór i oprac. Z. Łapiński, Wydawnictwo Literackie, Kraków 1984.

Witold Gombrowicz, Kosmos, Wydawnictwo Literackie, Kraków 1986.

Witold Gombrowicz, Przewodnik po filozofii w sześć godzin i kwadrans, Wydawnictwo Literackie, Kraków 2018.

Beata Guczalska, Jerzy Jarocki. Artysta teatru, Wydawnictwo PWST, Kraków 1999.

Beata Guczalska, Znaki chaosu czy sensu?, „Didaskalia” 2005, nr 70.

Marek Hendrykowski, Wspótczesna adaptacja filmowa, Wydawnictwo Naukowe UAM, Poznań 2011.

Joanna Jakubowska-Cichoń, Mowa przytaczana w narracjach Marguerite Duras, Universitas, Kraków 2010.

Jerzy Jarocki, Kosmos, Teatr Narodowy, Warszawa 2005.

Jerzy Jarzębski, Gry poetyckie i teatralne, Kraków 2018.

Jerzy Jarzębski, Gra w Gombrowicza, Warszawa 1982.

Jerzy Jarzębski, Natura i teatr. 16 tekstów o Gombrowiczu, Kraków 2007.

Elżbieta Konieczna, Jerzy Jarocki. Biografia, Kraków 2018.

List Witolda Gombrowicza do Tadeusza Byrskiego, „Słowo Ludu” 1957, nr 35.

Hans-Thies Lehmann, Teatr postdramatyczny, tłum. D. Sajewska, M. Sugiera, Księgarnia Akademicka, Kraków 2004.

Anna Litak, Czytanie genetyczne, „Teatr” 2018, nr 2.

Michał Paweł Markowski, Czarny nurt. Gombrowicz, świat, literatura, Wydawnictwo Literackie, Kraków 2004.

Marta Miłoszewska, Adaptacja. Skrzynka $z$ narzędziami, Akademia Teatralna im. Aleksandra Zelwerowicza w Warszawie, Warszawa 2017.

Jan Mukařovský, Wśród znaków i struktur, tłum. J. Baluch, M.R. Mayenowa, J. Mayen, L. Pszczołowska, PIW, Warszawa 1970.

Leonard Neuger, „Kosmos” Witolda Gombrowicza. Genologiczne podstawy hipotez sensowności, „Teksty Drugie” 1999, nr 6.

Brygida Pawłowska-Jądrzyk, Sens i chaos w grotesce literackiej, Universitas, Kraków 2002.

Patrice Pavis, Słownik terminów teatralnych, tłum. i oprac. S. Świontek, Ossolineum, Wrocław 2002.

Patrice Pavis, Współczesna inscenizacja, tłum. P. Olkusz, PWN, Warszawa 2011. 
Jean-Paul Sartre, Egzystencjalizm jest humanizmem, tłum. J. Krajewski, Wydawnictwo Muza, Warszawa 1998.

Herta Schmid, „Nagi palec”: teatralizacja przedmiotów w „Ślubie” Witolda Gombrowicza, „Pamiętnik Literacki” 1985, nr 76/4.

Dominik Sulej, „Kosmos” jako gabinet luster. Psychomachia Witolda Gombrowicza, Universitas, Kraków 2015.

E. Szczęsna, Twórcza zmiana. Medialne przetworzenia sztuki, [w:] Rejony twórczej zmiany. Tekst. Adaptacja. Medialna re-kreacja, red. B. Pawłowska-Jądrzyk,

K. Gołos-Dąbrowska, Wydawnictwo Naukowe UKSW, Warszawa 2019.

Tożsamość. 100 lat polskiej architektury, red. B. Stelmach, K. Andrzejewska-Batko, NIAiU, Warszawa 2019.

Andrzej Wirth, Teatr Jerzego Jarockiego, cz. II, tłum. D. Borkowska, „Dialog” 1991, nr 2. Tomasz Zielke, Powierzchnie Gombrowicza. „Tancerz mecenasa Kraykowskiego” i perwersja, „Twórczość” 2012, nr 10.

\section{Źródła ilustracji}

Il. 1. Pierwsza scena spektaklu - Witold spotyka Fuksa. Jerzy Jarocki, Kosmos, Teatr Telewizji, 2006. Kadr z nagrania spektaklu, https://ninateka.pl/vod/teatr/kosmos-jerzy-jarocki/ [dostęp 26.02.2021].

Il. 2. Jerzy Jarocki, Kosmos, Teatr Telewizji, 2006. Kadr z nagrania spektaklu, https:// ninateka.pl/vod/teatr/kosmos-jerzy-jarocki [dostęp 26.02.2021].

Il. 3. Podglądanie Leny przez Witolda. Jerzy Jarocki, Kosmos, Teatr Telewizji, 2006.

Kadr z nagrania spektaklu, https://ninateka.pl/vod/teatr/kosmos-jerzy-jarocki/ [dostęp 26.02.2021].

Il. 4. „Czarna msza” Leona. Jerzy Jarocki, Kosmos, Teatr Telewizji, 2006. Kadr z nagrania spektaklu, https://ninateka.pl/vod/teatr/kosmos-jerzy-jarocki [dostęp 26.02.2021].

Il. 5. Komunia z karmelków, Jerzy Jarocki, Kosmos, Teatr Telewizji, 2006. Kadr z nagrania spektaklu, https://ninateka.pl/vod/teatr/kosmos-jerzy-jarocki [dostęp 26.02.2021].

Il. 6. Rewizja w pokoju Katasi. Jerzy Jarocki, Kosmos, Teatr Telewizji, 2006. Kadr z nagrania spektaklu, https://ninateka.pl/vod/teatr/kosmos-jerzy-jarocki [dostęp 26.02.2021].

\section{From a Philosophical Novel to (Post) Epic Theater? Witold Gombrowicz's Cosmos Staged by Jerzy Jarocki}

The aim of the article is to present the way in which Jerzy Jarocki transforms Witold Gombrowicz's Cosmos into a theatrical script. The director does not try to extract a purely dramatic form from the novel, but creates a dramatization that takes into account the epic elements of the work. He proves with his realization 
that the producer does not have to deconstruct the work or even modernize it in order to introduce a discussion about the work and its readings to the stage. The scenography (created by Jerzy Juk-Kowarski) is extremely important in the context of the realization of the Cosmos, which allows the creators to place the staging in a specific philosophical context, enlivens the recipient's imagination and, in a way, forces an active reception of the work.

Keywords: Witold Gombrowicz, philosophical novel, Cosmos, Jerzy Jarocki, Jerzy Juk-Kowarski, adaptation

Data otrzymania tekstu: 25.03.2021 r.

Data zakończenia procesu recenzyjnego: 5.05.2021 r.

Data akceptacji tekstu do druku: 12.05.2021 r. 